\title{
MN-ANDALUSITE, SPESSARTINE, MN-GROSSULAR, PIEMONTITE AND MN-ZOISITE/CLINOZOISITE FROM TRIKORFO, THASSOS ISLAND, GREECE
}

\author{
Voudouris P. ${ }^{1}$, Graham I. ${ }^{2}$, Mavrogonatos K. ${ }^{1}$, Su S. ${ }^{2}$, Papavasiliou K. ${ }^{3}$, \\ Farmaki M.-V. ${ }^{1}$ and Panagiotidis P. ${ }^{1}$ \\ ${ }^{1}$ Department of Mineralogy and Petrology, Faculty of Geology and Geoenvironment, National and \\ Kapodistrian University of Athens, voudouris@geol.uoa.gr, \\ kmavrogon@geol.uoa.gr,mbfarmaki@yahoo.gr,parispanagiotidis@yahoo.gr \\ ${ }^{2}$ School of Biological, Earth and Environmental Sciences, University of New South Wales, Sydney, \\ NSW 2052 Australia,i.graham@unsw.edu.au,z3308907@zmail.unsw.edu.au \\ ${ }^{3}$ Department of Economic Geology \& Geochemistry, Faculty of Geology and Geoenvironment, \\ National and Kapodistrian University of Athens, kpapavas@geol.uoa.gr
}

\begin{abstract}
Mylonitized manganiferous schists and calc-silicate layers intercalated within amphibolite- to greenschist facies mica schists from the Trikorfo area (Thassos Island, Greece), host an unusual Mn-rich paragenesis of metamorphic silicate minerals, most of them in large, gemmy crystals. The silicates occur both in layers subparallel to the foliation and within discordant veins cross-cutting the metamorphic fabric. Piemontite (up to $12.7 \mathrm{wt} . \% \mathrm{Mn}_{2} \mathrm{O}_{3}$ ), $\mathrm{Mn}$-rich epidote (up to $7.8 \mathrm{wt}$. \% $\mathrm{Mn}_{2} \mathrm{O}_{3}$ ), $\mathrm{Mn}$-rich andalusite (up to $15.6 \mathrm{wt}$. \% $\mathrm{Mn}_{2} \mathrm{O}_{3}$ ), Mn-poor pink clinozoisite-epidote (up to $0.87 \mathrm{wt}$. \% $\mathrm{Mn}_{2} \mathrm{O}_{3}$ ), Mn-poor pink zoisite (up to $0.21 \mathrm{wt}$. \% $\mathrm{Mn}_{2} \mathrm{O}_{3}$ ), spessartine (up to $47.7 \mathrm{wt} . \% \mathrm{MnO}$ ) and $\mathrm{Mn}$-rich grossular (up to $3.6 \mathrm{wt}$. \% $\mathrm{MnO}$ ) are associated with diopside, hornblende, phlogopite, muscovite, tourmaline, hematite and iron-bearing kyanite. The studied assemblages are indicative of high $\mathrm{fO}_{2}$ conditions due to the presence of highly-oxidized pre-metamorphic Mn-rich mineral associations. They developed during prograde metamorphism of a Mn-rich sedimentary protolith(s), followed by re-equilibration to post-peak metamorphic conditions, vein formation and metasomatism during retrograde metamorphism accompanying the exhumation of the Thassos Island during the Oligocene-Miocene. Alternatively, the skarn-similar mineralogy of the calc-silicate layers could have been formed by fluids released by granitoids during contact metamorphism. The studied area represents a unique mineralogical geotope. Its geological-mineralogical heritage should be protected through establishment of a mineralogical-petrological geopark that will also promote sustainable development of the area.
\end{abstract}

Keywords: Mn-andalusite (viridine), Mn-zoisite (thulite), spessartine, geotope, Thassos Island.

\section{Пєрí}

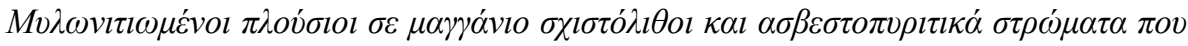

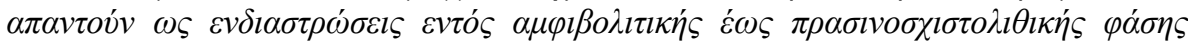

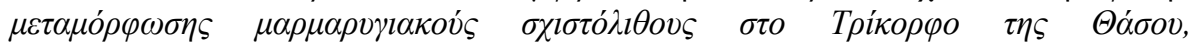




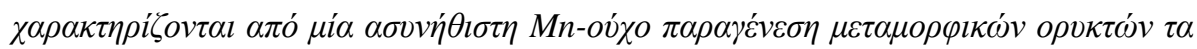

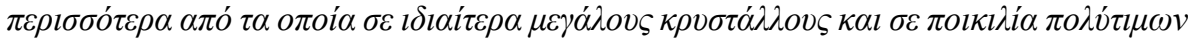

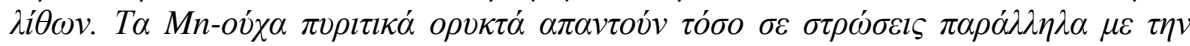

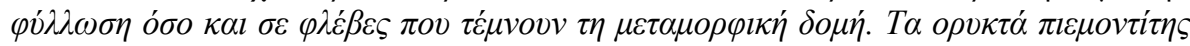

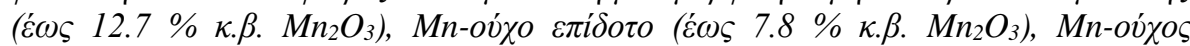

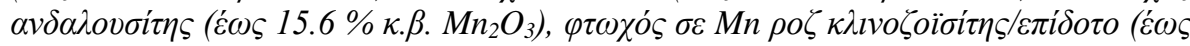

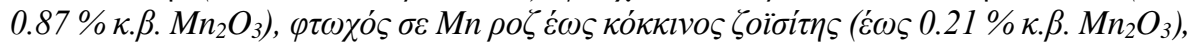

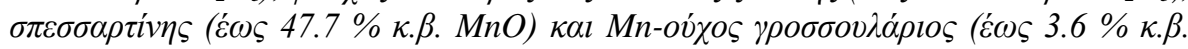

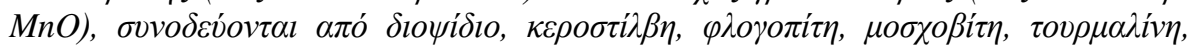

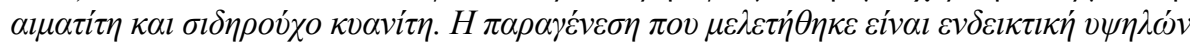

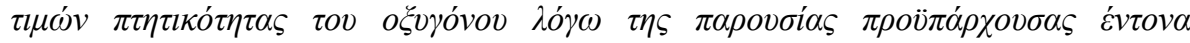

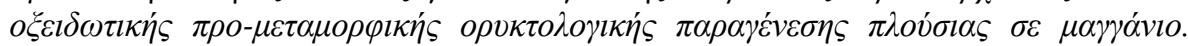

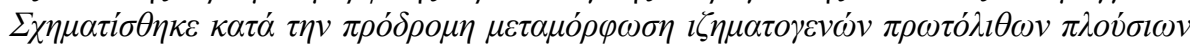

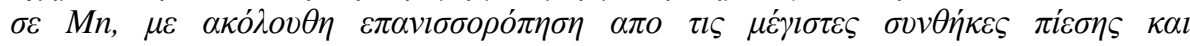

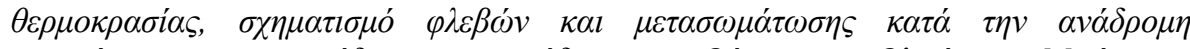

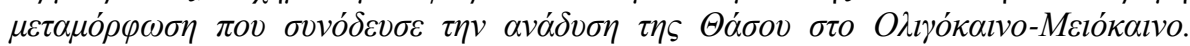

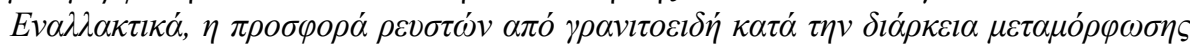

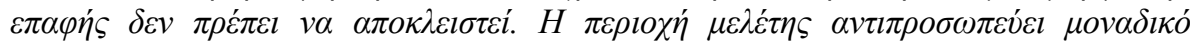

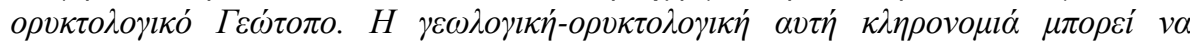

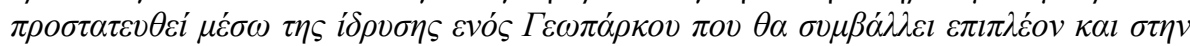

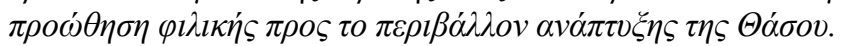

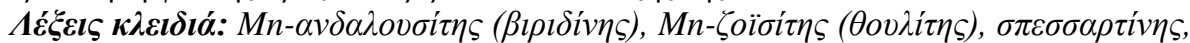

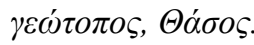

\section{Introduction}

Greece hosts several sites containing manganiferous minerals that formed in metamorphic environments, such as the Mn-rich metasediments of Andros and Evia islands (Reinecke, 1986), the high P/T Mn-bearing meta-conglomerates from northern Syros Island (Altherr et al., 2013) and the Mn-bearing meta-skarn on Paros Island (Paraskevopoulos, 1958). The Trikorfo area, Thassos Island, is characterized by an unusual manganiferous mineralogical assemblage hosted within metamorphic rocks of the Rhodope Massif, first described by Zachos (1982), and consist of piemontite, braunite, spessartine, dravite, thulite, epidote, kyanite, staurolite, titanite and hematite. Dimitriadis (1989) reported on the presence of pink pleochroic manganoan epidote in mica schists, as well as, biotitemuscovite-kyanite-sillimanite bearing schists, thus limiting peak metamorphic conditions to 600$650{ }^{\circ} \mathrm{C}$ at 4-7 kbar. Voudouris (2005) and Voudouris et al. $(2006,2012,2013)$, described in some detail the mineralogy and mineral-chemistry of the above manganiferous minerals and other silicates from Trikorfo (kyanite, tremolite, tourmaline, chlorite, etc) and reported on the discovery of $\mathrm{Mn}$ rich andalusite ((better known as viridine) in the area occurring within piemontite-spessartine schists and quartz veins as deep emerald-green-colored crystals up to $7 \mathrm{~cm}$. The $\mathrm{Mn}$-andalusite, spessartine and thulite from Trikorfo are of world class museum quality, and can be considered as potential gemstones (Voudouris et al., 2012). The aim of the current study is to present new data on the manganiferous silicate association(s) of Trikorfo, to describe the mineralogical and mineralchemical characteristics and discuss the role of various mechanisms in their formation through comparison it with other similar assemblages from elsewhere.

\section{Geology}

Thassos Island consists mainly of Permo-Carboniferous orthogneisses and marbles intercalated with amphibolites and metapelites interpreted as members of the Southern Rhodope Core Complex, and display an intense, penetrative top-to-the-southwest shearing under amphibolite and greenschist facies conditions (Brun and Sokoutis, 2007). The island comprises three dominant rock units from base to top, separated by two SW-dipping low-angle normal fault systems (Wawrzenitz and Krohe, 
1998; Brun and Sokoutis, 2007): (1) a lower unit, consisting mainly of marbles with intercalations of paragneisses and micaschists; (2) an intermediate unit consisting of orthogneisses, marbles with intercalations of paragneisses, mica-schists and amphibolites and (3) an upper unit, dominated by migmatites and gneisses. Two major tectonic events affected the above mentioned lithologies: a compressional phase (of pre-Mid-Eocene age) resulted in the thrusting of the gneisses and migmatites on top of the intermediate unit and an extensional ductile to brittle event that took place from 26-24 to $12 \mathrm{Ma}$, creating a NE-trending stretching lineation, foliated fabric and widespread boudinage formation (Wawrzenitz and Krohe, 1998; Brun and Sokoutis, 2007; Kounov et al., 2015). $\mathrm{Rb}-\mathrm{Sr}$ and $\mathrm{U}-\mathrm{Pb}$ dating by the above authors revealed a continuous cooling history of the ductile metamorphic rocks from $700^{\circ} \mathrm{C}$ to $300^{\circ} \mathrm{C}$ from 26 to $12 \mathrm{Ma}$.
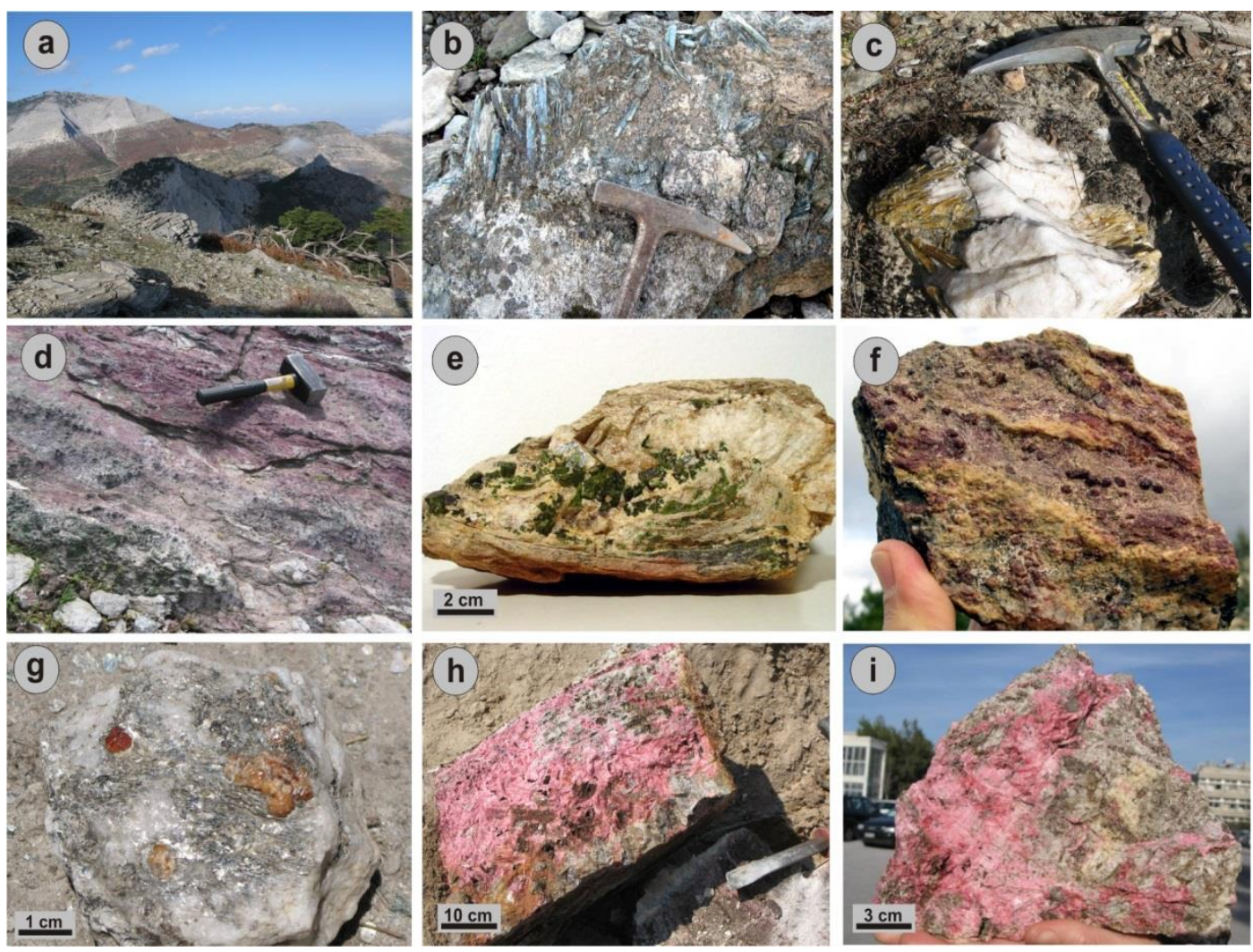

Figure 1 - (a) Panoramic view of the Trikorfo area, Thassos Island. (b) Blue kyanite crystals from quartz-feldspar lenses within mica schists. (c) Orange kyanite in quartz lense. (d) Outcrop of piemontite (purple) and Mn-andalusite (green) bearing schists. (e) Mn-andalusite crystals in quartz-feldspar lense. (f) Spessartine from piemontite-spessartine assemblage. (g) Gemmy spessartine with muscovite in quartz. (h,i) Mn-zoisite crystals with grossular and quartz from calc-silicate layers hosted within the mica schists.

The study area at Trikorfo is located along the major SW-dipping low-angle normal detachment zone (e.g. reactivated thrust) separating the lower from the intermediate unit at Thasos (Fig. 1a). Mica schists and orthogneisses predominate and tectonically overlay the marbles of Theologos (e.g. lower unit; Fig. 1a). Kyanite-sillimanite micaschists which are close to the main shear zone have formed in P-T conditions of $5.5 \pm 1.5 \mathrm{kbar}$ and $600 \pm 50^{\circ} \mathrm{C}$ and bear signs of incipient partial melting contemporaneous with the ductile fabric that is related to extensional deformation (Brun and Sokoutis, 2007). Quartz lenses within the mica schists mostly contain blue kyanite crystals, but in some cases green, yellow and orange kyanite are present (Fig. 1b, c), along with uncommon zoned kyanite crystals with dark blue cores and yellow-green rims. Piemontite-andalusite-muscovite, piemontite-spessartine-braunite- 
and kyanite-spessartine-muscovite schists are intercalated within the kyanite-bearing mica schists (Fig. 1d). Quartz- and quartzofeldspathic lenses inside the schists contain large crystals of Mn-andalusite, spessartine and piemontite (Fig. 1e to g). Calc-silicate layers (up to $80 \mathrm{~cm}$ wide) intercalated within the kyanite-bearing mica schists are mainly composed (from an outer band adjacent to host mica schists towards the centre of the layer) of tremolitic hornblende, diopside, quartz, plagioclase, Mnclinozoisite/epidote, grossular, titanite and Mn-zoisite (Figs 1h, i and 2a). An orthogneiss exposed in the area is composed of orthoclase, plagioclase (oligoclase-andesine) along with biotite, quartz, hematite, epidote and allanite and is surrounded by a transitional zone with the same mineralogy as the above mentioned calc-silicate layers (e.g. amphibole, plagioclase, Mn-clinozoisite/epidote from granitoid outwards; Fig. 2b, c). Allanite is an accessory mineral of the orthogneiss and is associated with andesine, epidote and biotite (Fig. 2d).
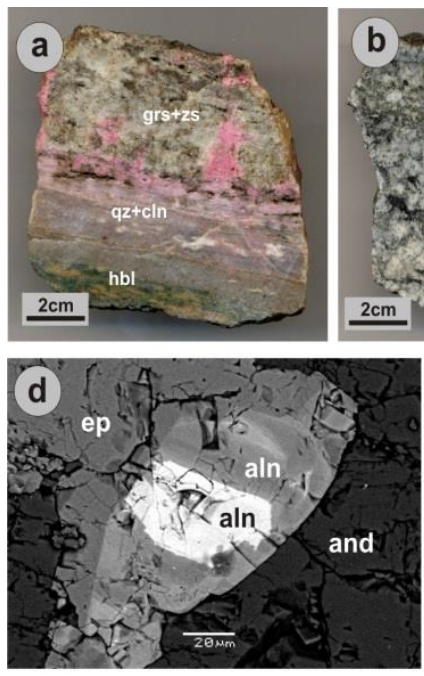
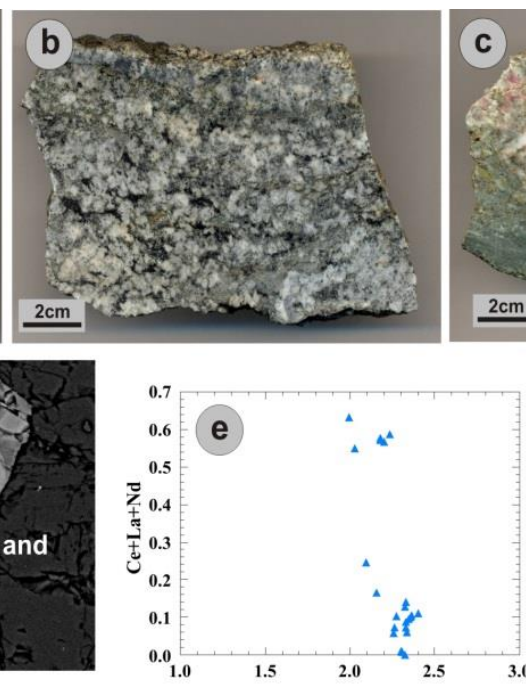

$\mathbf{A l}_{\mathrm{tu}}$

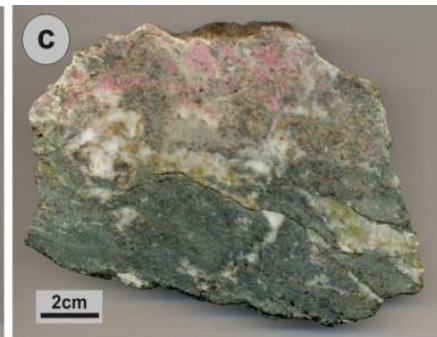

La

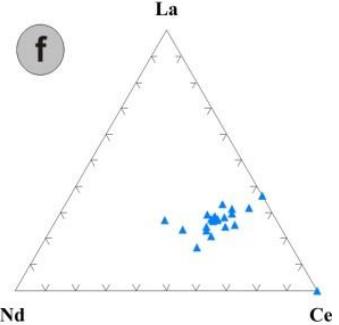

Figure 2 - (a) Hand-specimen of calc-silicate layer demonstrating mineralogical zonation with a tremolitic hornblende $(\mathrm{hbl})$, diopside and plagioclase rich zone proximal to the mica schist, grading into a quartz- pink clinozoisite/epidote $(q z+c l n)$ zone and then into a Mngrossular - Mn-zoisite (grs+zs) zone in the centre of the layer. (b) Hand-specimen of mylonitized orthogneiss consisting of biotite and feldspars, sample GA6. (c) Hand-specimen

from the transitional zone between the orthogneiss and the mica schists, consisting of tremolitic hornblende, feldspar, quartz, green epidote and Mn-poor pink epidote/clinozoisite, sample GA7, 7a. (d) Photomicrograph (BSE-image) showing chemically-zoned allanite (aln) in association with epidote (ep) and andesine (and), sample GA6. (e) REE (Ce+La+Nd) vs

$\mathrm{Al}_{\text {tot }}$ plot of the analysed allanite and REE-poor epidote from the previous sample, demonstrating negative correlation between $\mathrm{Al}^{3+}$ and $\mathrm{REE}^{3+}$. (f) Ternary La-Nd-Ce plot demonstrating chemical variation of analysed allanites.

\section{Materials and Methods}

Twenty five thin and polished sections from 11 representative samples (TH1-8, GA6, GA7, GA7a) of Mn-rich minerals and their host rocks were studied in detail by optical microscopy. Sample TH1, TH2 and TH3 are calc-silicate rocks consisting of grossular, Mn-clinozoisite/epidote, Mn-zoisite, tremolitic hornblende and quartz. Sample TH4 is spessartine-piemontite-braunite-hornblende schist. Sample TH5 is piemontite-Mn andalusite-muscovite schist. Sample TH6 represents quartz lenses inside mica schists including green epidote. Sample TH7 consists of blue kyanite and TH8 represents quartz lenses with orange kyanite. Sample GA6 is an orthogneiss. Samples GA7, GA7a are from the transitional zone between the orthogneiss and the surrounding metapelites. A total of fifteen thin-and-polished 
sections were studied by scanning electron microscopy using a Jeol-JSM 5600 SEM equipped with back-scattered imaging capabilities and a Cameca SX 100 wavelength-dispersive electron microprobe, at the universities of Athens and Hamburg, respectively. Operating conditions were as follows: for the Jeol-JSM 5600 SEM, accelerating voltage was $20 \mathrm{kV}$, beam current $0.5 \mathrm{nA}$, time of measurement $50 \mathrm{sec}$ and beam diameter $1-2 \mu \mathrm{m}$; for the Cameca SX 100 , accelerating voltage was $20 \mathrm{kV}$, beam current $0.2 \mathrm{nA}$ and beam diameter $1 \mu \mathrm{m}$. In addition, XRD analyses were carried-out using a Siemens (Brooker) $5005 \mathrm{X}$-ray diffractometer at the University of Athens. Operating conditions were: $\mathrm{Cu} \mathrm{K} \alpha$ radiation at $40 \mathrm{kV}, 40 \mathrm{nA}$ and $0.02^{\circ}$ step time. The XRD patterns were evaluated using the EVA 10.0 program of the Siemens DIFFRACplus and the D5005 software package.

\section{Mineralogy and mineral chemistry}

Kyanite in blue, green, yellow to orange coloured crystals up to $20 \mathrm{~cm}$, is found in quartz \pm feldspar lenses intercalated with the schists (Fig. 1b, c). Orange kyanite also occurs in association with spessartine, biotite (phlogopite), muscovite and oligoclase. Kyanite forms euhedral prisms rimmed by muscovite (Fig. 3a). Microprobe analyses for orange kyanite indicate no $\mathrm{Mn}_{2} \mathrm{O}_{3}$ and up to 1.07 wt. $\% \mathrm{Fe}_{2} \mathrm{O}_{3}$ in the structural formula, which probably contributes to the coloration of the crystals (Table 1).

Mn-andalusite (formerly Viridine) in dark green-colored euhedral to subhedral crystals up to $7 \mathrm{~cm}$ is found in piemontite mica schists or quartz-feldspar lenses (Fig. 1d, e). Mn-andalusite also occurs in massive quartz lenses in association with muscovite, and in kyanite-muscovite schists, where it replaces orange kyanite. In andalusite-piemontite schists the viridine is associated with piemontite and quartz (Fig. 3b), or with plagioclase (anorthite), phlogopite and muscovite (Fig. 3c), or with spessartine and muscovite (Fig. 3d) and accompanies opaque Mn-oxides. Microprobe data revealed relatively elevated $\mathrm{Mn}_{2} \mathrm{O}_{3}$ contents, up to 15.55 wt. \%, corresponding up to 0.351 apfu (Table 1). The substitution of $\mathrm{Al}^{3+}$ by $\mathrm{Mn}^{3+}$ in the mineral formula is demonstrated in Figures 4a,b.

Spessartine and Mn-grossular are usually found (a) in "piemontite"-spessartine-braunite-quartz and spessartine-muscovite-quartz lenses intercalated within andalusite-piemontite-spessartine schists and within mica schists respectively (Fig. 1f,g), (b) in the andalusite-piemontite-spessartine schists and (c) in the calc-silicate layers consisting mainly of Mn-clinozoisite/epidote, Mn-zoisite and Mn-grossular (Figs 1h, i and 2a). Spessartine and Mn-grossular are also found in fissure veins crosscutting the above lithologies and were described in a previous study (Voudouris et al., 2010). Within the "piemontite"-spessartine-braunite-quartz aggregates, the spessartine commonly forms large euhedral crystals with numerous inclusions of piemontite and is surrounded by piemontite and magnesio-hornblende (Fig. 3e). Spessartine from the andalusite-piemontite-spessartine schists is also associated with muscovite, phlogopite, anorthite and hematite. Spessartine from quartzmuscovite lenses within mica schists forms translucent, orange-coloured, gem-quality euhedral crystals up to $1 \mathrm{~cm}$. Electron microprobe analyses of spessartine indicate $\mathrm{MnO}$ contents in the range of 37.75 .12 - 47.7 wt. \% (Table 1). Mn-bearing grossular from the calc-silicate layers, forms euhedral yellowish crystals of gem-quality in close association with pink to red coloured Mn-zoisite and quartz (Figs. 1i, 2a and 3h,i). MnO content ranges from 1.92 to 3.60 wt. \% (Table 1). All data are plotted in the ternary Mn-Ca-Fe diagram (Fig. 4c).

Epidote group minerals are represented in the study area by the Mn-bearing minerals piemontite, red-purple Mn-epidote, pink to red Mn-clinozoisite/epidote, typical green epidote and allanite. Electron microprobe analyses are presented in Table 1 and all data are plotted in Figures 2 and 4d. 

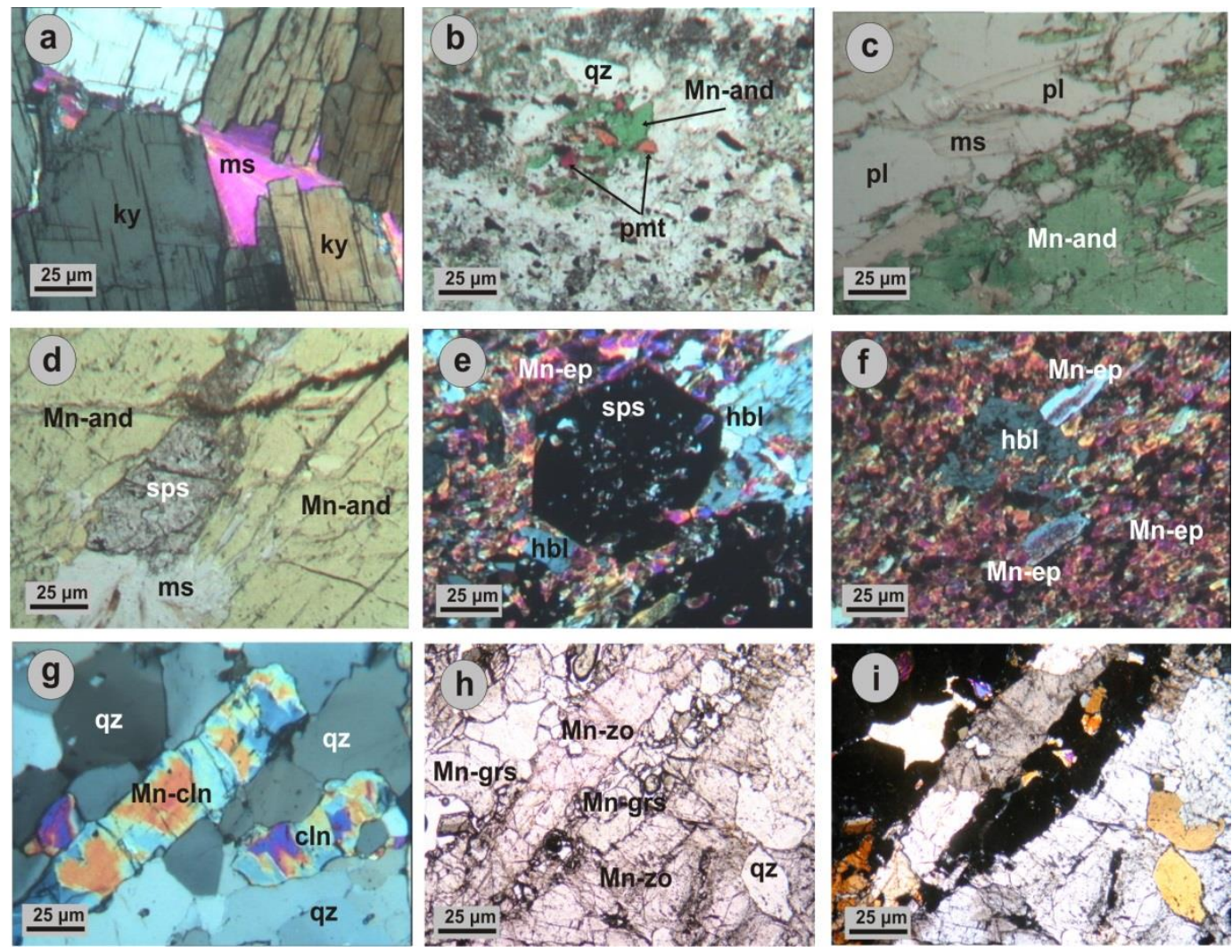

Figure 3 - Photomicrographs demonstrating mineralogical assemblages from the studied area. (a) kyanite (ky) in association with muscovite (ms), sample TH8, \# nicols. (b) piemontite (pmt) and Mn-andalusite (Mn-and) set in a fine-grained matrix dominated by quartz (qz), sample TH5, // nicols. (c) Mn-andalusite in association with plagioclase (pl) and muscovite, sample TH5, // nicols. (d) Mn andalusite associated with spessartine (sps) and muscovite, sample TH5, // nicols. (e) spessartine associated with Mn-rich epidote (Mn-ep) and magnesiohornblende (hbl) from "piemontite"-spessartine-braunite-quartz aggregates, sample TH4, \# nicols. (f) Magnesio-hornblende surrounded by Mn-rich epidote, some of which are intensely zoned, sample TH4, \# nicols. (g) Mn-poor clinozoisite (Mn-cln) from the intermediate part of

the calc-silicate layers, sample TH2, \# nicols. (h, // and i, \# nicols respectively) typical assemblage of Mn-zoisite (Mn-zo), Mn-grossular (Mn-grs) and quartz from the innermost part of the calc-silicate layers, samples TH3.

Piemontite and Mn-rich epidote usually accompany Mn-andalusite, spessartine, quartz, hematite and Mn-oxides in piemontite-spessartine-andalusite mica schists and in "piemontite"-spessartinebraunite-quartz aggregates, respectively (Fig. 1d). Within the piemontite-spessartine-andalusite schists, the piemontite is associated with Mn-andalusite (Fig. 3b).

Mn-rich epidote from the "piemontite"-spessartine-braunite-quartz aggregates occurs with spessartine and magnesio-bearing hornblende (Fig. 3e,f). In both cases piemontite and Mn-rich epidote forms dark purple-coloured prismatic crystals with typical piemontite pleochroism. Microprobe analyses revealed true piemontite (sensu-stricto) for the andalusite-bearing schists with $\mathrm{Mn}_{2} \mathrm{O}_{3}$ content up to 12.69 wt. \% and Mn-rich epidotes for the "piemontite"-spessartine-braunitequartz aggregates with $\mathrm{Mn}_{2} \mathrm{O}_{3}$ in the range of 1.9 to 7.8 wt. \% (Table 1 and Fig. 4 d). 
Table 1 - Representative electron microprobe data of Spessartine (1-3), Mn-Grossular (4-6), Piemonite (7-9), Mn-rich epidote (10,11) MnClinozoisite (12-14), Zoisite (15-17), Mn-Andalusite (18-20) and Fe-Kyanite (21). (bd): below detection.

\begin{tabular}{|c|c|c|c|c|c|c|c|c|c|c|c|c|c|c|c|c|c|c|c|c|c|}
\hline $\mathrm{Wt} \%$ & 1 & 2 & 3 & 4 & 5 & 6 & 7 & 8 & 9 & 10 & 11 & 12 & 13 & 14 & 15 & 16 & 17 & 18 & 19 & 20 & 21 \\
\hline $\mathrm{SiO}_{2}$ & 35.87 & 35.71 & 34.31 & 39.85 & 39.70 & 40.18 & 36.01 & 36.51 & 36.36 & 37.06 & 36.73 & 37.34 & 37.05 & 37.17 & 39.23 & 39.11 & 39.42 & 34.57 & 34.63 & 34.26 & 36.73 \\
\hline $\mathrm{Al}_{2} \mathrm{O}_{3}$ & 20.65 & 20.78 & 23.40 & 22.27 & 22.46 & 22.65 & 21.48 & 20.98 & 20.89 & 22.69 & 25.40 & 26.83 & 25.59 & 26.11 & 32.71 & 32.11 & 32.78 & 48.26 & 49.01 & 48.03 & 62.92 \\
\hline $\mathrm{MgO}$ & 1.94 & 0.31 & 0.41 & bd & bd & bd & 0.06 & 0.07 & 0.06 & 0.11 & 0.06 & 0.10 & 0.04 & 0.05 & 0.02 & 0.10 & 0.01 & 0.13 & 0.15 & 0.13 & bd \\
\hline $\mathrm{FeO}$ & 0.53 & 0.08 & 0.52 & 0.90 & 0.87 & 0.73 & - & - & - & - & - & - & - & - & - & - & 1.54 & - & - & - & - \\
\hline $\mathrm{Fe}_{2} \mathrm{O}_{3}$ & - & - & - & - & - & - & 6.53 & 6.83 & 6.32 & 8.44 & 10.46 & 9.28 & 9.84 & 10.83 & 1.55 & 2.01 & - & 3.38 & 2.80 & 2.79 & 1.06 \\
\hline $\mathrm{MnO}$ & 41.12 & 47.70 & 44.95 & 2.46 & 3.60 & 1.92 & - & - & - & & 3.63 & 0.24 & - & - & - & - & - & - & - & - & - \\
\hline $\mathrm{Mn}_{2} \mathrm{O}_{3}$ & - & - & - & - & - & - & 12.38 & 12.12 & 11.75 & 6.97 & - & 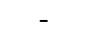 & 0.23 & 0.26 & 0.15 & 0.21 & 0.17 & 15.26 & 15.01 & 15.55 & bd \\
\hline $\mathrm{CaO}$ & 3.47 & 0.55 & 0.93 & 34.07 & 33.08 & 34.43 & 21.27 & 21.34 & 21.56 & 21.60 & 21.40 & 23.78 & 23.40 & 23.60 & 24.78 & 24.73 & 24.66 & 0.01 & 0.01 & bd & bd \\
\hline $\mathrm{K}_{2} \mathrm{O}$ & bd & bd & bd & bd & bd & bd & bd & bd & bd & bd & 0.06 & 0.01 & bd & bd & bd & bd & bd & bd & bd & bd & bd \\
\hline $\mathrm{Na}_{2} \mathrm{O}$ & bd & bd & bd & 0.09 & 0.32 & 0.06 & bd & 0.01 & bd & bd & 0.07 & bd & bd & bd & bd & bd & bd & bd & bd & bd & bd \\
\hline $\mathrm{TiO}_{2}$ & 0.25 & 0.09 & 0.05 & bd & bd & bd & bd & bd & bd & 0.06 & 0.06 & bd & bd & bd & 0.02 & 0.04 & 0.05 & 0.02 & 0.04 & 0.02 & bd \\
\hline Total & 99.71 & 100.38 & 100.07 & 99.74 & 100.12 & 100.08 & 97.73 & 97.86 & 96.94 & 96.93 & 95.87 & 97.28 & 97.15 & 98.02 & 98.44 & 98.31 & 98.58 & 100.11 & 100.09 & 99.21 & 100.71 \\
\hline & \multicolumn{6}{|c|}{$24(\mathrm{O})$} & \multicolumn{11}{|c|}{8 cations } & \multicolumn{4}{|c|}{$5(\mathrm{O})$} \\
\hline $\mathrm{Si}$ & 5.849 & 5.880 & 5.616 & 6.019 & 5.985 & 6.018 & 3.006 & 2.969 & 2.967 & 2.983 & 2.913 & 2.930 & 2.940 & 2.924 & 2.970 & 2.970 & 2.920 & 1.015 & 1.013 & 1.015 & 0.987 \\
\hline $\mathrm{Al}$ & 3.968 & 4.032 & 4.517 & 3.967 & 3.984 & 4.000 & 2.151 & 2.006 & 2.009 & 2.153 & 2.374 & 2.481 & 2.393 & 2.420 & 2.918 & 2.874 & 2.920 & 1.671 & 1.690 & 1.678 & 1.994 \\
\hline $\mathrm{Mg}$ & 0.471 & 0.083 & 0.100 & 0.000 & 0.000 & 0.000 & 0.008 & 0.089 & 0.008 & 0.014 & 0.007 & 0.011 & 0.005 & 0.006 & 0.003 & 0.011 & 0.001 & 0.006 & 0.007 & 0.006 & 0.000 \\
\hline $\mathrm{Fe}^{2+}$ & 0.073 & 0.011 & 0.071 & 0.120 & 0.120 & 0.102 & 0.418 & 0.417 & 0.388 & 0.000 & 0.000 & 0.000 & 0.000 & 0.000 & 0.000 & 0.000 & 0.000 & 0.000 & 0.000 & 0.000 & 0.000 \\
\hline $\mathrm{Fe}^{3+}$ & 0.000 & 0.000 & 0.000 & 0.000 & 0.000 & 0.000 & 0.000 & 0.000 & 0.000 & 0.512 & 0.624 & 0.643 & 0.647 & 0.643 & 0.088 & 0.115 & 0.089 & 0.074 & 0.062 & 0.062 & 0.021 \\
\hline $\mathrm{Mn}^{2+}$ & 5.103 & 5.980 & 5.603 & 0.308 & 0.462 & 0.239 & 0.000 & 0.000 & 0.000 & 0.000 & 0.270 & 0.016 & 0.000 & 0.000 & 0.000 & 0.000 & 0.000 & 0.341 & 0.334 & 0.351 & 0.000 \\
\hline $\mathrm{Mn}^{3+}$ & 0.000 & 0.000 & 0.000 & 0.000 & 0.000 & 0.000 & 0.800 & 0.749 & 0.730 & 0.475 & 0.000 & 0.000 & 0.016 & 0.012 & 0.010 & 0.014 & 0.011 & 0.000 & 0.000 & 0.000 & 0.000 \\
\hline $\mathrm{Ca}$ & 0.606 & 0.160 & 0.163 & 5.506 & 5.352 & 5.540 & 1.936 & 1.854 & 1.886 & 1.862 & 1.790 & 1.999 & 1.989 & 1.990 & 2.010 & 2.013 & 1.998 & 0.000 & 0.000 & 0.000 & 0.000 \\
\hline K & 0.000 & 0.000 & 0.000 & 0.000 & 0.000 & 0.000 & 0.000 & 0.000 & 0.000 & 0.000 & 0.000 & 0.000 & 0.000 & 0.000 & 0.000 & 0.000 & 0.000 & 0.000 & 0.000 & 0.000 & 0.000 \\
\hline $\mathrm{Na}$ & 0.000 & 0.000 & 0.000 & 0.034 & 0.086 & 0.017 & 0.000 & 0.001 & 0.000 & 0.000 & 0.011 & 0.000 & 0.000 & 0.000 & 0.000 & 0.000 & 0.000 & 0.000 & 0.000 & 0.000 & 0.000 \\
\hline $\mathrm{Ti}$ & 0.030 & 0.008 & 0.006 & 0.000 & 0.000 & 0.000 & 0.000 & 0.000 & 0.000 & 0.010 & 0.003 & 0.000 & 0.000 & 0.000 & 0.001 & 0.002 & 0.003 & 0.008 & 0.004 & 0.000 & 0.000 \\
\hline
\end{tabular}


Mn-poor clinozoisite/epidote occurs in euhedral to subhedral crystals that vary in colour from light pink to red, usually found in the intermediate zone of the calc-silicate layers (Fig. 2a) mostly associated with quartz (Fig. 3g), plagioclase (anorthite-bytownite), titanite, diopside and tremolitic hornblende. Available microprobe data revealed $\mathrm{Fe}_{2} \mathrm{O}_{3}$ content varying from 1.84-10.83 wt. \%, and minor $\mathrm{Mn}_{2} \mathrm{O}_{3}$ content ranging from 0.02 to 0.87 wt. $\%$.

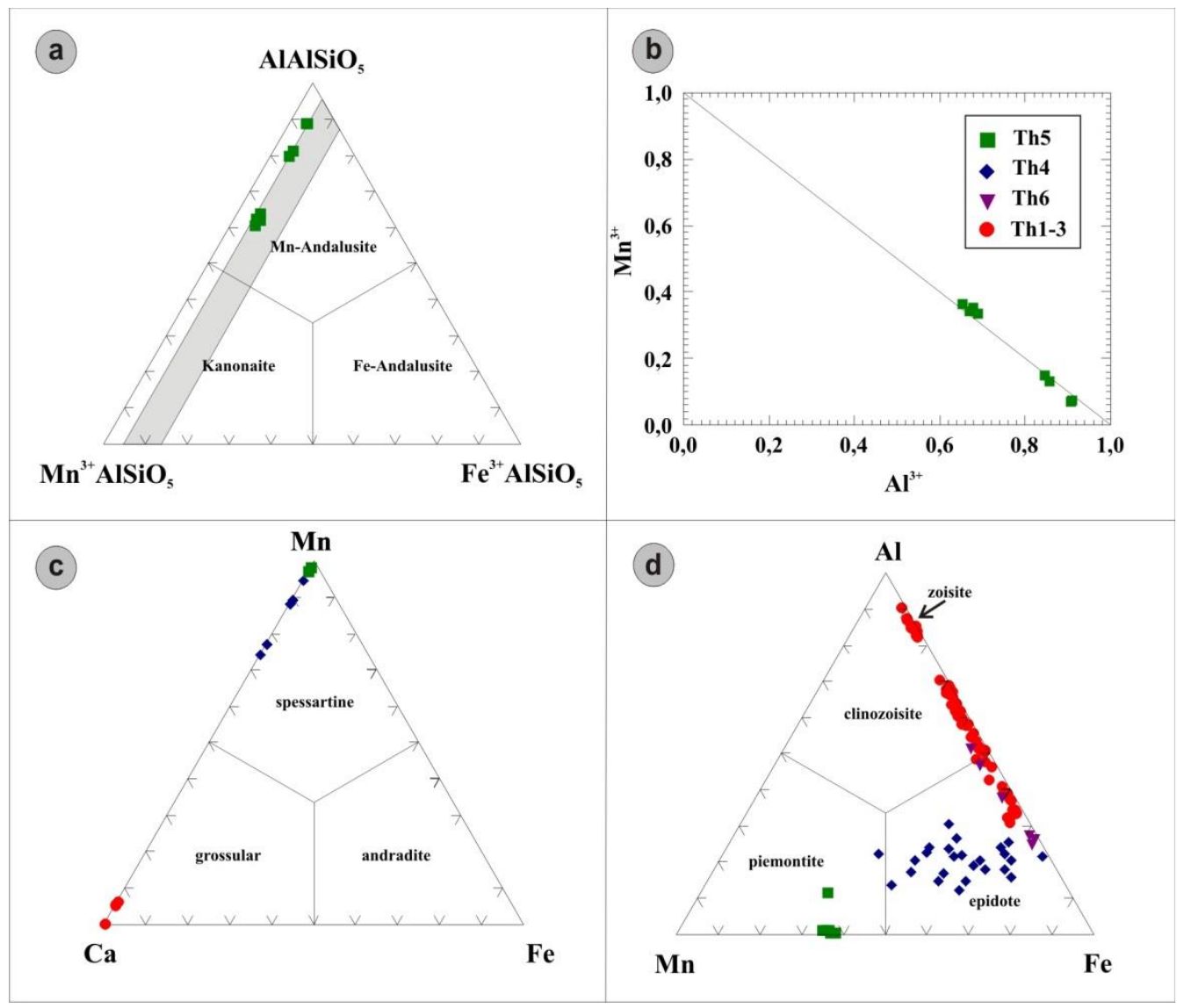

Figure 4 - (a) Compositions of the analysed Mn-andalusite plotted in the ternary $\mathrm{Al}_{2} \mathrm{SiO}_{5}$ $\mathrm{Fe}_{2} \mathrm{O}_{5}-\mathrm{Mn}_{2} \mathrm{SiO}_{5}$ diagram. Shaded area demonstrates chemical compositions of andalusitekannonaite from Novák and Škoda (2007). (b) binary plot demonstrating partial substitution of $\mathrm{Al}^{3+}$ by $\mathrm{Mn}^{3+}$ in the analysed Mn-andalusite. (c) Compositions of garnets plotted in the ternary Mn-Fe-Ca diagram. (d) Ternary Al-Mn-Fe plot of the analysed epidote-group minerals from the studied area. Al refers to $X_{c l n}, M n$ to $X_{p m t}$ and Fe to $X_{\text {ep. }}$ Mn-poor zoisite is also plotted for comparison (based on Franz and Liebscher, 2004, Armbruster et al., 2006).

Mn-poor zoisite (var. thulite) is found in the inner part of the calc-silicate layers, intergrown with Mn-grossular, titanite and quartz, both in the matrix of the rock and in fissures cross-cutting the foliation. It occurs in light pink to red colors and forms translucent subhedral to euhedral crystals up to $10 \mathrm{~cm}$ (Figs. 1h, i and 2a, 3h, i). Available electron microprobe data revealed low $\mathrm{Fe}_{2} \mathrm{O}_{3}$ content (1.52-2.00 wt. \%) and very low $\mathrm{Mn}_{2} \mathrm{O}_{3}$ values from $0.15-0.21 \mathrm{wt}$. \%, enough to be responsible for the pink-red coloration (see Discussion).

Green epidote is often formed at the outer margins of the calc-silicate layers and in the orthogneiss and (meta)skarn (Fig 2c, d), along with hornblende and feldspar (andesine). It contains 0.15 to 0.58 wt. $\% \mathrm{MnO}$. 
REE-bearing epidote and allanite occur as accessory minerals in the orthogneiss and are rimmed by REE-free epidote, in association with andesine, orthoclase and biotite (Fig. 2d). Analytical data revealed that allanite from the Trikorfo area is rich in $\mathrm{Ce}_{2} \mathrm{O}_{3}, \mathrm{La}_{2} \mathrm{O}_{3}$ and $\mathrm{Nd}_{2} \mathrm{O}_{3}$ (up to 9.4, 5.1 and 7.2 wt. \% respectively) and has relatively poor $\mathrm{Al}_{2} \mathrm{O}_{3}$ content, as incorporation of trivalent rare earth elements in the $\mathrm{A} 2$ (divalent) site is compensated by an increase of $\mathrm{Fe}^{2+}$ in the $\mathrm{M} 3$ site with concomitant decrease of $\mathrm{Al}^{3+}$ (Fig. 2e, f).

Mn-bearing varieties of diopside (up to $1.0 \mathrm{wt}$ \% $\mathrm{MnO}$ ), tremolitic hornblende (up to $0.7 \mathrm{wt}$ \% $\mathrm{MnO}$ ), magnesio-hornblende (up to $2.3 \mathrm{wt}$. \% $\mathrm{MnO}$ ), phlogopite (up to $2.2 \mathrm{wt} . \% \mathrm{MnO}$ ) and chlorite (up to $1.4 \mathrm{wt}$. \% MnO), accompany the manganiferous association at Trikorfo. Accessory phases include monazite (relatively abundant in discrete layers), sphene and zircon. Tourmaline is very abundant in quartz-feldspar lenses within mica schists, where it occurs in black crystals (var. schorlite) up to $10 \mathrm{~cm}$ and is associated with muscovite and chlorite. Olive green-colored tourmaline (crystals up to $3 \mathrm{~cm}$ ) is also present, however these were not analysed in the present study. Tourmaline is also present in fissures intergrown with chlorite, titanite and quartz (Voudouris et al., 2010). Finally, tremolite in white crystals up to $10 \mathrm{~cm}$ was observed in sheared marbles.

\section{Discussion and Conclusions}

Co-existing $\mathrm{Al}_{2} \mathrm{SiO}_{5}$ polymorphs occur in various metamorphic rocks and formed either during regional metamorphism or a combination of regional and contact metamorphism (Larson and Sharp, 2003; Sepahi et al., 2004). The peak metamorphic conditions at Trikorfo are muscovite-sillimanitekyanite facies, at about $5.5 \pm 1.5 \mathrm{kbar}$ and $600 \pm 50^{\circ} \mathrm{C}$ and occur along the shear zone separating the lower from the intermediate units on the island (Dimitriadis, 1989; Brun and Sokoutis, 2007). Among the studied mineralogical assemblages at Trikorfo, high-medium grade associations include kyanite-garnet-muscovite-biotite-plagioclase and these were retrogressed to lower-grade assemblages (e.g. epidote group minerals, titanite, chlorite, albite) during the exhumation stage of decompression and cooling, in accordance to Dimitriadis (1989) and Wawrzenitz and Krohe (1998). Mn-andalusite might have formed during decompression in veins within host rocks containing kyanite (e.g. Kerrich, 1990).

Field and mineralogical evidence suggest that the zoisite-grossular-bearing calc-silicate layers represent local inhomogeneities in the bedding of the sedimentary protoliths and/or compositional changes that have been produced by metasomatic processes during regional metamorphism, as suggested for similar layers at Therapio, Evros area by Kassoli-Fournaraki et al. (1995). In this sense, the mineralogy of the calc-silicate layers could have developed during prograde metamorphism of a Mn-rich, calcareous pelitic protolith, followed by vein formation and metasomatism during retrograde metamorphism accompanying the exhumation of the Thassos Island during the Oligocene-Miocene.

Alternatively, the skarn-similar mineralogy of the calc-silicate layers could have been formed by fluids released by granitoids during contact metamorphism. With the lack of radiometric data, the exact age (e.g. Hercynian?) of the orthogneiss at Trikorfo is not known. Miocene granitoids are not exposed at Thassos Island, however a burried granitoid is considered by Melfos and Voudouris (2016) to be genetically related to the widespread Miocene intrusion-related gold mineralization in the area. Tourmaline at Trikorfo also occurs as a retrograde mineral, and according to van Hinsberg et al. (2011) metasomatic introduction of boron on the retrograde path, is most commonly associated with the intrusion of late granites in orogenic belts. This is in accordance to Kassoli-Fournaraki and Michailidis (1994) who stated that the tourmaline-quartz veins formed prior to deformation and metamorphism, but they do not exclude a further retrograde development.

In addition to the calc-silicate layers, the piemontite-andalusite-spessartite-hornblende-hematite in the schists are typical metamorphic mineral assemblages characteristic of highly oxidized premetamorphic Mn-rich sedimentary rocks, metamorphosed under amphibolite- to greenschist facies 
conditions, as for example at Tanzania, the Hidaka area/ Japan and New Mexico/USA (Meinhold and Frish, 1970; Bonazzi and Menchetti, 2004).

The presence of Mn-bearing andalusite in the studied assemblage indicates very high $f_{2} \mathrm{O}_{2}$ values, as experimentally demonstrated for the incorporation of $\mathrm{Mn}^{3+}$ into the andalusite structure (AbsWurmbach and Peters, 1999). Electron microprobe analyses of Mn-andalusites from the Trikorfo revealed that $\mathrm{Mn}_{2} \mathrm{O}_{3}$ can reach up to 15.55 wt. \% (0.351 apfu). The $\mathrm{Mn}^{3+}$ substitutes for $\mathrm{Al}^{3+}$ in the formula of the mineral which corresponds to $(\mathrm{Al}, \mathrm{Mn})_{2} \mathrm{SiO}_{5}$ as also reported by Novák and Škoda (2007). The Mn-poor clinozoisite/epidote and Mn-poor zoisite from the Trikorfo area contain up to 0.9 wt. $\% \mathrm{Mn}_{2} \mathrm{O}_{3}$ which is responsible for their pink to red color, in accordance to Bonazzi and Menchetti (2004) and Franz and Liebscher (2004) that coloration in pink epidotes/clinozoisites is due to $\mathrm{Mn}^{3+}$ and not $\mathrm{Mn}^{2+}$ in the mineral structure. Future petrographic, isotopic and geochemical studies will help better understand the genetic implications of manganiferous minerals at Thasos Island. Some of these minerals can be considered as gemstones, however, the Trikorfo site is a worldwide unique Geotope that should be protected through integration in a mineralogical Geopark under promotion of sustainable development in the broad area.

\section{Acknowledgments}

The authors would like to thank Stefanie Heidrich (Institute for Mineralogy and Petrography, University of Hamburg) for the support at the electron microprobe and Peter Stutz (Institute for Mineralogy and Petrography, University of Hamburg) for the preparation of polished thin sections. Finally we greatly thank the reviewers Prof. A. Magganas and Assist. Professor L. Papadopoulou for constructive comments which highly improved the initial manuscript.

\section{References}

Abs-Wurmbach, I. and Peters, T., 1999. The Mn-Al-Si-O system: an experimental study of phase relations applied to paragenesis in manganese-rich ores and rocks, Eur. J. Mineral., 11, 45-68.

Altherr, R., Soder, C., Panienka, S., Peters, D. and Meyer, H.P., 2013. Pink manganian phengite in a high P/T meta-conglomerate from northern Syros (Cyclades, Greece), Contrib Mineral Petrol, 166, 1323-1334.

Armbruster, T., Bonazzi, P., Akasaka, M., Bermanec, V., Chopin, C., Giere, R., Heuss-Assbicheler, S., Liebscher, A., Menchetti, S., Pan, Y. and Pasero, M., 2006. Recommended nomenclature of epidote-group minerals, Eur. J. Mineral., 18, 551-567.

Bonazzi, P. and Menchetti, S., 2004. Manganese in Monoclinic Members of the Epidote Group: Piemontite and Related Minerals, Rev. Miner. Geochem., 56, 495-551.

Brun, J.P. and Socoutis, D., 2007. Kinematics of the Southern Rhodope Core Compex (North Greece), Int. J Earth Sci., 96, 1079-1099.

Dimitriadis, E., 1989. Sillimanite grade metamorphism in Thasos island, Rhodope massif, Greece and its regional significance, Geologica Rhodopica, 1, 190-201.

Franz, G. and Liebscher, A., 2004. Physical and chemical properties of the epidote minerals - an Introduction, Rev. Miner. Geochem., 56, 1-81.

Kassoli-Fournaraki, A. and Michailidis, K., 1994. Chemical composition of tourmaline in quartz veins from Nea Roda and Thasos areas in Macedonia, northern Greece, Can. Mineral., 32, 607-615.

Kassoli-Fournaraki, A., Michailidis, K., Zannas, I. and Zachos, S., 1995. Titanite-rich carbonates from the Therapio area in Thrace, Northern Greece: contraints of the mineral assemblage formation, Schweiz. Mineral. Petrogr. Mitt., 75, 387-398.

Kerrick, D.M., 1999. The $\mathrm{Al}_{2} \mathrm{SiO}_{5}$ polymorphs, Reviews in Mineralogy, $406 \mathrm{pp}$.

Kounov, A., Wüthrich, E., Seward, D., Burg, J.P. and Stockli, D., 2015. Low-temperature constraints on the Cenozoic thermal evolution of the Southern Rhodope Core Complex (Northern Greece), Int. J. Earth Sci., 104, 1337-1352.

Larson, T.E. and Sharp, Z.D., 2003. Stable isotope constraints on the $\mathrm{Al}_{2} \mathrm{SiO}_{5}$ "triple-point" rocks from 
the Proterozoic Priest pluton contact aureole, New Mexico, USA, J. Metam. Geol., 21, 785-798.

Meinhold, K.D. and Frisch, T., 1970. Manganese-silicate-bearing metamorphic rocks from central Tanzania, Schweiz. Mineral. Petrogr. Mitt., 50, 493-507.

Melfos, V. and Voudouris, P., 2016. Fluid evolution in Tertiary magmatic-hydrothermal ore systems at the Rhodope metallogenic province, NE Greece, A review, Geologia Croatica, 69(1), 157-167.

Novák, M. and Škoda, R., 2007. $\mathrm{Mn}^{3+}$-rich andalusite to kannonaite and their breakdown products from metamamganolite at Kojetice near Trebic, the Moldanubian Zone, Czech Republic. Journal of Geosciences, 52, 161-167.

Paraskevopoulos, G., 1958. Die Entstehung der Manganlagerstaetten auf der Insel Paros, Griechenland, N. Jb. Min. Abh., 90(3), 367-380.

Reinecke, T., 1986. Phase relationships of sursassite and other manganese-silicates in highly oxidized low-grade metamorphic rocks from Evia and Andros Islands, Greece, Contrib. Mineral. Petrol., 94, 110-126.

Sepahi, A.A., Whitney, D.L. and Baharifar, A.A., 2004. Petrogenesis of andalusite-kyanitesillimanite veins and host rocks, Sanandaj-Sirjan metamorphic belt, Hamadan, Iran, J. Metam. Geol., 22, 119-134.

Van Hinsberg, V.J., Henry, D.J. and Dutrow, B.L., 2011. Tourmaline as a petrologic forensic mineral: a unique recorder of its geologic past, Elements, 7, 327-332.

Voudouris, P., 2005. Minerals of Eastern Macedonia and Western Thrace: Geological framework and environment of formation, Bull. Geol. Soc. Greece, 37, 62-77.

Voudouris, P., Melfos, V. and Katerinopoulos, A., 2006. Precious stones in Greece: Mineralogy and geological environment of formation. Understanding the genesis of ore deposits to meet the demand of the 21 st century, $12^{\text {th }}$ Quadrennial IAGOD symposium, Moscow, 6p, CD-ROM volume.

Voudouris, P., Graham, I., Melfos, V., Sutherland, L. and Zaw, K., 2012. Gemstones in Greece: Mineralogy and crystallizing environment, 34th IGC conference, Brisbane, Australia, August 2012.

Voudouris, P., Constantinidou, S., Kati, M., Mavrogonatos, C., Kanellopoulos, C. and Volioti, E., 2013.Genesis of alpinotype fissure minerals from Thasos Island, northern Greece. Mineralogy, mineral chemistry and crystallizing environment, Bull. Geol. Soc. Greece, 47, 468-476.

Wawrzenitz, N. and Krohe, A., 1998. Exhumation and doming of the Thasos metamorphic core complex (S Rhodope, Greece): structural and geochronological constraints. Tectonophysics, 285, 301-332.

Zachos, S., 1982. Geological map of Greece, Thassos sheet. Scale 1:50000, Greek Institute of Geological and Mining Research, Athens, Greece. 